\title{
Yksittäisen hoitokäynnin tarkastelusta pitkäaikaissairaan vuorovaikutussuhteiden verkoston tarkasteluun
}

\section{Maija Gerlander, Teija Lukkari \& Tarja Kettunen}

Kun poskiontelo- tai silmätulehdus vaivaa, asia hoituu usein yhdellä hoitokäynnillä. Sen sijaan yhtä tai useampaa pitkäaikaissairautta potevalla voi olla lukuisia hoitokäyntejä ja tutkimusvaiheita, pitkäkestoinen, jopa elinikäinen lääkitys, toistuvia kuntoutusjaksoja ja sairauden aiheuttamia liitännäissairauksia. Vuosien varrella pitkäaikaissairaalle kehkeytyy monivaiheinen hoitohistoria lukuisine vuorovaikutussuhteineen ja dokumentteineen. Näin ollen yksittäisen hoitokäynnin tarkastelu ei anna osuvaa kuvaa ajan myötä kutoutuneesta vuorovaikutussuhteiden verkostosta, eikä se myöskään kovin laajasti tavoita sairauteen ja hoitoon liittyvää problemaattisuutta, jota pitkäaikaissairaat kohtaavat.

Tämän puheenvuoron taustalla on pitkäaikainen kiinnostuksemme terveysviestinnän ja hyvinvoinnin kysymyksiin puheviestinnän tutkijoina ja kouluttajina. Lisäksi erityisenä sytykkeenä ovat olleet omat ja lähipiirimme kokemukset perusterveydenhuollon ja erikoissairaanhoidon potilaina. Puheenvuorossamme keskitymme muutamaan keskeisenä pitämäämme teemaan pitkäaikaissairaan näkökulmasta katsottuna. Käsittelemme vuorovaikutussuhteiden verkostoa: sen rakentamista, ylläpitoa ja siirtymiä verkostossa, vuorovaikutuksen jännitteitä sekä tarvittavaa tukea ja dokumentaatiota. Pyrimme käsittelemään asioita konkreettisten esimerkkien pohjalta. Lopuksi kokoamme keskeisiä kysymyksiä, jotka mielestämme toimivat sekä tutkimusteemoina että käytännön toiminnan kehittämiskohteina.

Näemme pitkäaikaissairaan hoitoon liittyvät vuorovaikutussuhteet laajasti niin, että niihin sisältyy myös potilasta koskeva dokumentaatio, joka itsessään on ainakin osin vuorovaikutuksen tulosta ja joka asettuu vuorovaikutussuhteissa erilaisten tulkintojen kohteeksi. Tutkimustulokset, diagnoosit ja hoitomääräykset eivät ole vain "puhdasta asiaa", vaan niissä samalla tuotetaan potilaan asemaa ja niiden tulkintaan voi potilaalla liit- 
tyä vahvoja tunteita, kuten ahdistusta ja pelkoa. Fokuksemme ei myöskään ole pelkästään hoidonantajan ja potilaan välisessä vuorovaikutuksessa, vaan sisällytämme siihen myös hoito-organisaation ja asiakkaan ja hoitoorganisaatioiden väliset vuorovaikutussuhteet. Käytämme puheenvuorossamme pääasiassa potilas-käsitettä, emmekä tässä tartu asiakas- ja potilas-käsitteiden väliseen problematiikkaan.

\section{Verkostonäkökulma pitkäaikaissairaan vuorovaikutus- suhteisiin}

Pitkäaikaissairauden toteaminen on monille merkittävä käännekohta, joka muuttaa omaa ja läheisten elämää: arkeen tulee tutkimuksia, hoitoja, lääkitystä, oireiden ja lääkityksen vaikutusten seurantaa. Vuorovaikutuksen näkökulmasta potilaan elämään rakentuu väistämättä monenlaisia sairauteen ja sen hoitoon liittyviä vuorovaikutussuhteita, osa hoitoprosessin tuottamia, osa potilaan itsensä luomia. Kokonaisuutena potilaan sairauden hoitamiseen liittyvässä verkostossa on hyvin erilaisia osallistujia ja sitä voidaan tarkastella eri tasoilta. Potilaalla on vuorovaikutussuhteita useisiin terveydenhoidon ammattilaisiin (esim. lääkäri, hoitaja, ravitsemusterapeutti, fysioterapeutti, farmaseutti), joita hän tapaa terveyskeskuksessa, sairaalassa tai kuntoutusyksikössä, yksityisesti ja/tai julkisesti tuotetuissa palveluissa. Lisäksi hoidon toteuttamiseen voivat osallistua omaishoitajat tai muut lähipiiriin kuuluvat, jotka ovat myös suhteessa hoidonammattilaisiin, joko samoissa kohtaamisissa kuin potilas tai erikseen. Potilaan asiaan kytkeytyy myös hoito-organisaation ja potilaan väliset viestintäsuhteet: hoito-organisaatiosta lähetetään esim. tutkimus- ja hoitokutsuja, tutkimustuloksia sekä hoito-ohjeita. Hoito-organisaatiossa potilasta koskevaa tietoa välitetään ja tulkitaan asiantuntijoiden keskinäisissä vuorovaikutussuhteissa. Lisäksi asiantuntijat voivat olla eri organisaatiossa. Sairaalasta lähtevän potilaan hoito voi jatkua terveyskeskuksessa ja toisinpäin, jolloin vuorovaikutussuhde ei ole vain ammattilaisten vaan myös hoito-organisaatioiden välinen. Kaikissa em. suhteissa osa potilaan asiasta välittyy ammattilaisten tuottamien dokumentaatioiden ja muiden asiakirjojen avulla, jotka kiertävät osassa verkostoa tulkintojen ja päätöksenteon pohjana.

Yksittäisten kohtaamisten sijasta mielestämme on olennaista kysyä, miten toimiva verkosto vuorovaikutussuhteista muodostuu. Verkoston merkitystä korostaa esimerkiksi Savundranayagamin (2013) havainto siitä, että potilaiden kyvyttömyys tai taitamattomuus ei ole pelkästään yksilön ominaisuus vaan yksilön, potilaan ja hänen kontekstinsa, kuten hoitoon liittyvien vuorovaikutussuhteiden tulos. Toinen tärkeä kysymys on, millai- 
set mahdollisuudet pitkäaikaissairaalla on vaikuttaa syntyvään verkostoon. Saako hän apua toimivan - ei liian suppean mutta ei liian laajan - verkoston ylläpitämiseen? Voisiko potilas olla vahvemmin vuorovaikutusverkoston hallitsija, joka voisi kutsua asiantuntijat koolle? Tätä mahdollisuutta järjestelmä ei tunne. Hätätilanteessa hoitava tiimi rakentuu ympärille pyytämättä. Sen sijaan pitkäaikaissairas, jolla ei ole akuuttia hengenvaaraa, mutta jolle voi kehittyä akuutteja liitännäissairauksia ja joka haluaisi saada kokonaisvaltaisesti tilanteensa käsiteltyä, ei pysty itse kutsumaan koolle esimerkiksi erikoisalojen lääkäreitä. Potilas ei ole verkoston hallitsija vaan pakotettu yksittäisiin asiantuntijakäynteihin käynti käynnin perään, mikä pahimmillaan lisää epävarmuutta eikä poista sitä.

\section{Siirtymät ja jännitteet pitkäaikaissairaan vuorovaikutus- verkostossa}

Siirtymät koskettavat pitkäaikaissairaan elämää kahdella tavalla: toisaalta on sairauden ja hoidon vaiheisiin liittyviä siirtymiä ja toisaalta niihin osittain liittyviä organisatorisia siirtymiä ammattilaiselta toiselle ja/tai hoitoorganisaatiosta toiseen. Tiedetään esimerkiksi, että hoidonammattilaisten välinen huono viestintä liittyy huonoihin hoitotuloksiin ja puutteellisiin siirtymiin hoitoyksiköstä toiseen. Sen sijaan erikoissairaanhoidon ja perusterveydenhuollon ammattilaisten välinen kunnioitus ja luottamus edistävät potilaan luottamusta saamaansa hoitoon. (Ks. Brez ym. 2009.) Siirtymiin liittyy vuorovaikutussuhteiden kannalta mielestämme erityisesti seuraavat jännitteet: a) kertomisen ja suojaamisen jännite, jossa kyse on esimerkiksi siitä, mitä kerrotaan ja jätetään kertomatta suullisesti tai dokumentaatiossa, b) ennustettavuuden ja yllätyksellisyyden jännite, joka liittyy siihen, miten suunniteltua hoito ja verkostojen rakentaminen on tai miten ne näyttäytyvät vuorovaikutussuhteen osapuolille sekä c) autonomisuuden ja riippuvaisuuden jännite, jossa ydin on potilaan mahdollisuudessa toimia ja vaikuttaa hoitoonsa ja siihen liittyvän vuorovaikutusverkoston rakentumiseen (jännitteisyydestä ks. Baxter 2010).

Kertomisen ja kertomatta jättämisen teemat tulevat esille tiedon tulkinnan ja edelleen välittämisen kysymyksissä. Millaista tietoa potilaan täytyy itse kertoa hoidonantajille, mikä omaa asiaa koskevasta tiedosta välittyy eteenpäin ja voiko tiedon välittymiseen luottaa? Potilas voi havaita olevansa eräänlainen ammattilaisten välisen vuorovaikutuksen sanansaattaja, Hermes-hahmo ja vastuullinen tulkitsija. Hän voi joutua selvittelemään esimerkiksi magneettikuviensa tilannetta sekä vaatimaan niiden lähettämistä erikoissairaanhoitoon. Minne pitää soittaa ja milloin? Vaikka doku- 
menttien siirtyminen hoito-organisaatiosta toiseen helpottuu lähivuosina, käytännössä potilas on ja voi joutua olemaan omien dokumenttiensa paras asiantuntija. Tiedon siirtyminen ei takaa sitä, että tietoa halutaan ja ehditään hoitokäynneillä käyttää riittävästi. Tarpeen olisi lyhyt tiivistys siitä, mitä vuoden aikana on tapahtunut sen sijaan että käsiteltävänä on kymmenien sivujen mittainen epikriisi siitä, mitä on tapahtunut ja tehty tai suunniteltu tehtäväksi (esim. Brez ym. 2009). Milloin sähköinen terveysja hoitosuunnitelma (Komulainen ym. 2011) kykenee vastaamaan tähän haasteeseen?

Potilas voi myös joutua tulkitsijan vastuulliseen rooliin silloin, kun hänellä on kaksi pitkäaikaissairautta, joiden hoitamiseen osallistuvat useat erikoislääkärit. Tällöin potilaalla on huoli siitä, kertooko hän vastaanotoilla oikeat ja olennaiset asiat, joita esimerkiksi hoidosta vastaavien silmälääkärin, reumatologin, hammaslääkärin, endokrinologin, kardiologin ja/ tai gynekologin pitäisi tietää. Osaako hän poimia relevantit tiedot? Vaikka potilaalle on kertynyt kokemustietoa omista sairauksistaan, vaaditaan aikamoista lääketieteen asiantuntijuutta, että voisi tämän tehdä. Tehtävä voi tuntua raskaalta, vaikka siihen olisi etukäteen valmistautunut, sillä vastaanottoaikaa ei useinkaan ole kovin paljon. "Onko kysyttävää"-kysymys käynnin viime hetkillä sanottuna näyttäytyy lähinnä retorisena. Olennaisimmat kysymykset tulevat käynnin jälkeen, mikä tutkimusten pohjalta hyvin tiedetään (esim. Henselmans ym. 2014). Millaisia voisivatkaan olla ne toimintakäytännöt, jotka helpottaisivat tätä tilannetta?

Hämmennystä voivat tuottaa asiantuntijoiden ristiriitaiset näkemykset esimerkiksi lääkityksestä tai hoitotoimenpiteistä. Jos toinen lääkäri sanoo, että sairaus ei vaikuta tiettyihin arvoihin tai oireisiin ja toinen sanoo, että vaikuttaa, miten potilasta autetaan käsittelemään tätä ristiriitaa? Ohitetaanko ja vaietaanko näkemysten erilaisuus vai pyritäänkö sitä tarkastelemaan ja tekemään ymmärrettäväksi? Tällöin punnitaan sitä, mitä käytännössä tarkoittaa avoimuus ja avoin keskustelu, joita pidetään yleisesti tärkeinä arvoina myös terveydenhuollossa. Suojataanko kertomatta jättämisellä potilasta liialta tiedolta vai omia ja ammattikunnan kasvoja eriävien mielipiteiden tai vastakkaisten argumenttien käsittelyltä? Millaisia käytäntöjä voitaisiin kehittää potilaan tueksi näihin hetkiin?

Ennustettavuus ja yllätyksellisyys näyttäytyvät pitkäaikaissairaan vuorovaikutussuhteissa tietämättömyytenä hoito-organisaatioon ja hoitoon liittyvistä käytänteistä. Potilas voi olla tietämätön esimerkiksi siitä, miten asiat etenevät, miksi mitäkin tehdään ja ketkä ovat mukana. Käsitteet, vaiheet ja toimenpiteet ovat niin itsestään selviä hoidon asiantuntijoille, ettei niitä tulla avanneeksi potilaalle. Tällöin se, mikä organisaation taholta on 
suunnitelmallista, näyttäytyykin potilaalle suunnittelemattomuutena aiheuttaen epävarmuutta ja pelkoa. Erityisesti yllätyksellisyyden ja ennustettavuuden kysymykset konkretisoituvat siirtymäkohdissa, kun sairaala tai osasto vaihtuu tai terveydentilassa tapahtuu muutoksia.

\section{Millaista autonomisuutta odotetaan?}

Terveydenhoidon strategisissa linjauksissa (ks. esim. Sosiaali- ja terveysministeriö 2012) potilaan halutaan osallistuvan ja ottavan yhä enemmän vastuuta omasta hoidostaan ja häntä tulisi siinä myös tukea. Erityisesti vastuullisuus ja vastuuttaminen omasta hoidosta on suunnattu pitkäaikaissairaille, joiden hoito on usein elinikäistä ja siten myös kustannuksiltaan terveydenhoitojärjestelmää kuormittavaa. Toisaalta potilaalta odotetaan oma-aloitteisuutta ja aktiivista osallistumista oman hoidon suhteen, mutta toisaalta riippuvaisuus ja passiivisuus voikin käytännössä olla se asema, jota odotetaan ja tarjotaan. Oleellinen kysymys on, mitä osallistumisella ja vastuullisuudella milloinkin tarkoitetaan ja kuka sen määrittää.

Jos potilaalle kerrotaan vain, että hänelle tulee kirjallinen kutsu ilman tietoa, keneltä hän voi halutessaan kysyä asiastaan, potilaalle tarjotaan pelkästään passiivisen odottelijan roolia. Käytännössä hän voi jäädä seurailemaan postiluukun mahdollista kolahdusta. Osallistumista tukisi esimerkiksi yhteystietojen antaminen, tieto siitä, miten hoito jatkuu (kuka ottaa yhteyttä, miten ja missä ajassa) ja mitä potilas voi tehdä itse. Miksi potilaalle ei vieläkään automaattisesti tarjota mahdollisuutta kysyä mieltä askarruttavista asioista tietyltä taholta hoitokäynnin jälkeen? Se olisi myös potilaan aktiivisuuden ja autonomisuuden tukemista, vai ajatellaanko, että autonomisuuden nimissä, vastuu asioiden selvittämisestä ja selviämisestä eteenpäin on potilaalla. Järjestelmä luo ja pitää yllä passiivisuutta. Liian vähän on avattu esimerkiksi hoitoprosesseja julkisesti nähtäville. Hoitoa koskevien asioiden selvittäminen monesta eri paikasta turhauttaa, herättää aggressioita ja voi tuottaa myös välinpitämättömyyttä omahoitoon. Voidaan vakavasti kysyä, voimaantuuko pitkäaikaissairas omahoidossa?

Passiivinen odottaminen sisäänrakennettuna potilaan asemana ilmenee myös vastaanotto- ja poliklinikkakäytänteissä. Potilas voi joutua odottamaan vuoroaan, eikä kukaan välttämättä kerro, että vastaanotto on myöhässä tai anna arviota myöhästymisen kestosta. Entä kun huonokuntoisen potilaan odotusaika venyy, eikä kukaan tule kertomaan tilanteesta hänelle? Kaikilla ei ole saattajaa mukana, joka kyselisi aktiivisesti hänen puolestaan. Tämä on hämmentävää. Vaikka aikataulujen joustaminen on hoitotyöhön sisältyvä piirre, siitä kertomatta jättämisen ei pitäisi olla. 
Kiinnostavasti Haslbeck ja Schaffer (2009) toteavat tutkimuksessaan, että pitkäaikaissairaiden odotettiin pikemminkin asettuvan passiivisen potilaan rooliin sen sijaan että heidän aktiivisuudelleen olisi annettu aikaa. Lääkärit keskittyivät ensisijaisesti sairauden tai lääketieteelliseen hoidon tarkkailuun, eivätkä esimerkiksi pitkäaikaissairaan potilaan lääkehoidon toteuttamisen haasteisiin tai emotionaaliseen tukemiseen. Tutkija toteavat, että monella pitkäaikaissairaalla oli kuitenkin runsaasti eri lähteistä peräisin olevaa tutkimus- ja asiantuntijatietoa oman kokemustietonsa lisäksi, joten he olisivat pystyneet ja halunneet osallistua vahvemmin oman hoitonsa suunnitteluun ja toteuttamiseen.

\section{Millaista tukea erityisesti tarvitaan?}

Sairastavan tuen tarve tiedetään ja tunnustetaan. Tutkimuskirjallisuudessa tuki jaotellaan usein tiedolliseen, välineelliseen, emotionaaliseen, käytännölliseen ja taloudelliseen tukeen, suhteiden ylläpitämisen ja ohjaamisen tukeen sekä tukeen arviointiapuna (Mikkola 2009). Mutta millaista erityistä tukea pitkäaikaissairas tarvitsee sairauden ja hoidon eri vaiheissa ja verkoston rakentumisessa?

Pitkäaikaissairailla on runsaasti tietoa sairaudestaan, joka pohjautuu muuan muassa useisiin vastaanottokäynteihin ja niissä käytyihin keskusteluihin, dokumentteihin, potilaan kokemustietoon sekä esimerkiksi internetistä saatavilla olevaan tietoon sairaudesta. Haasteeksi nouseekin tiedon analysointi (esim. tiedon suuri määrä ja ymmärrettävyys, vertaisten kauhukertomukset) ja arviointi (mikä on oleellista), johon hän tarvitsisi hoitohenkilöstön asiantuntevaa tukea. Miten esimerkiksi tulkita lääkärin kommenttia, joka on herättänyt potilaassa hämmennystä ja epävarmuutta. Joskus käy niin, että vähentääkseen epävarmuutta potilas joutuu menemään toiselle erikoislääkärille. Haasteena voi tällöin olla, minkä alan erikoislääkärin apua kulloinkin tarvitaan. Mistä potilas voisi saada asiantuntevaa tukea arviointiin?

Pitkäaikaissairauksille on tyypillistä useiden lääkkeiden käyttö rinnakkain ja limittäin. Tällöin potilaan on usein hankala arvioida ja luokitella oireitaan: mikä liittyy sairauden ns. normaalikulkuun tai esimerkiksi ikääntymiseen ja mitkä ovat lääkkeisiin tai niiden yhteisvaikutukseen liittyviä ja milloin oireista pitäisi olla huolissaan. Tähän arviointiin potilas tarvitsee lääkärin ja joskus eri alojen lääkäreiden tukea. On myös todettu, että pitkäaikaissairaat tarvitsevat realistista arviointia sairauden uhkista ja lääkehoitoon liittyvistä ongelmista luodakseen arkeensa toimivat käytänteet (Haslbeck ja Shaeffer 2009). 
Pitkäaikaissairas tarvitsee erityisesti prosessiin liittyvää tukea. Kuinka hän voisi valmistautua sairauteen ja hoitoon liittyviin vaiheisiin ja näin hallita paremmin ennakoitavuuden ja yllätyksellisyyden jännitettä? Mistä potilas saisi tietoa erityisistä sairautensa oireista, mitä silloin tehdään ja keihin hoitoverkostossa ollaan yhteydessä?

Pitkäaikaissairaus voi kestää koko elämän. Tällöin potilas tarvitsisi erityisesti hoitohenkilöstön emotionaalista tukea (esim. Bretz ym. 2009). Kuitenkin kokemustemme perusteella emotionaalinen tuki jää liian usein potilaan ja hänen lähipiirinsä vastuulle, vaikka usein myös lähipiiri olisi emotionaalisen tuen tarpeessa. Lähipiiri voi esimerkiksi tietää potilaan tilanteen vakavuuden potilasta paremmin, jolloin he voivat tarvita apua asiasta keskustelemiseen. Emotionaalisen tuen tarvetta eli sitä, miten potilas jaksaa hoitoja ja parantumattoman tai etenevän sairauden eri vaiheita ja miten hän pystyy elämään tiedon kanssa, tulisi suunnitella sekä analysoida hoidon eri vaiheissa. Tieto tukea antavasta hoitoverkostosta on pitkäaikaissairaan jaksamisen kannalta keskeinen.

\section{Pohdittavaa tutkimukselle ja koulutukselle}

Tutkimuksellisesti pitkäaikaissairaiden vuorovaikutussuhteet ovat jääneet interpersonaalisen terveysviestinnän tutkimuksissa katveeseen: keskeisin tutkimuskohde on ollut terveydenhoidon ammattilaisen ja asiakkaan välinen viestintä (esim. Kreps 2012). Suurin osa tutkimuksista on toteutettu poikittaistutkimuksina yksittäisistä viestintätilanteista. Jatkuvuus, esimerkiksi potilaan vuorovaikutussuhteita seuraamalla ja verkostojen tarkastelu ovat harvoin sisäänrakennettuna tutkimusasetelmiin. Edellä käsittelemiemme teemojen pohjalta esitämme kysymyksiä, jotka ovat mielestämme tärkeitä pohdittaessa pitkäaikaissairaan vuorovaikutusverkostoja. Ne tulisi nostaa näkyvämmin sekä terveysviestinnän tutkimuksen että terveydenhuollon koulutuksen kohteeksi.

Ensimmäisenä ovat rakentuvaa verkostoa koskevat kysymykset. Millainen verkosto pitkäaikaissairaan vuorovaikutussuhteista muodostuu? Miten verkosto rakentuu, kuinka sitä ylläpidetään ja kuinka se on dokumentoitu? Kuka tätä verkostoa hallitsee ja ohjaa? Millainen rooli potilaalla on erilaisissa vuorovaikutussuhteissa ja -verkostossa? Miten tulkinnat esimerkiksi potilaan tilanteesta sekä hoidosta muotoutuvat ja muuttuvat verkostossa? Entä miten vuorovaikutuksen jännitteet verkostossa ilmenevät?

Toiseksi voidaan tarkastella toimivan verkoston luonnetta. Millainen verkosto parhaiten tukisi kussakin tilanteessa sekä potilasta lähipiireineen että hoitohenkilöstöä? Keitä verkostossa pitäisi olla ja mitkä siirtymät ovat 
keskeisiä? Miten verkoston suunnitelmallista rakentamista tuetaan?

Kolmantena näkökulmana ovat tukeen ja analysointiin liittyvät kysymykset. Miten pitkäaikaissairaan sekä hänen lähipiirinsä emotionaalinen tukeminen huomioidaan verkostossa ja sairauden eri vaiheissa? Miten pitkäaikaissairasta autetaan analysoimaan ja arvioimaan verkostosta saamaansa tietoa ja sairauden eri vaiheissa tarvittavaa tukea? Lopuksi voidaan kysyä koulutukseen ja tutkimukseen liittyen, kuinka viestinnän koulutusta ja tutkimusta hyödynnetään verkoston rakentamisessa, ylläpitämisessä, analysoinnissa sekä dokumentoinnissa.

\section{Kirjallisuus}

Baxter, L. A. 2010. Voicing relationships. A dialogic perspective. Los Angeles: Sage.

Brez, S., Rowan, M., Malcolm, J., Izzi, S., Maranger, J., Liddy, C., Keely, E. \& Chye, T. 2009. Transition from specialist to primary diabetes care: A qualitative study of perspectives of primary care physicians. BMC Family Practice 2009, 10:39.

Haslbeck J. W. \& Schaffer, D. 2009. Routines in medication management: the perspective of people with chronic conditions. Chronic Illness 5, 184-196.

Henselmans, I., Heijmans, M., Rademakers, J. \& van Dulmen, S. 2014. Participation of chronic patients in medical consultations: patients' perceived efficacy, barriers and interest in support. Health Expectations. DOI: 10.1111/hex. 12206.

Komulainen, J., Vuokko, R. \& Mäkelä. M. 2011. Rakenteinen terveys- ja hoitosuunnitelma. THL- Luokitukset, termistöt ja tilasto-ohjeet 7. Tampere: Juvenes Print.

Kreps, G. L. 2012. Engaging health communication. Teoksessa T. J. Socha $\&$ M. J. Pitts (toim.) The positive side of interpersonal communication. New York: Peter Lang.

Mikkola, L. 2009. Sosiaalinen tuki työssä: katsaus 2000-luvun tutkimuskirjallisuuteen. Prologi. Puheviestinnän vuosikirja, 26-47.

Savundranayagam, M. Y. 2013. Receiving while giving: The differential roles of receiving help and satisfaction with help on caregiver rewards among spouses and adult-children. International Journal of Geriatric Psychiatry 29, 41-48.

Sosiaali- ja terveydenhuollon kansallinen kehittämisohjelma (Kaste) 2012-2015. STM julkaisuja 2012:1. Tampere. 